meiras horas de desenvolvimento do modelo de biofilm in vitro. Observaram-se reduções significativas na contagem dos patógenos periodontais P. gingivalis $(97,3 \%)$, A. actinomycetemcomitans $(84,0 \%)$ e F. nucleatum $(75,7 \%)$ nos biofilms tratados com o extrato, sem afetar a viabilidade bacteriana $(\mathrm{p}<0,001)$. Em relação a P. gingivalis, o patógeno periodontal cuja adesão bacteriana foi mais afetada pelo extrato, obteve-se

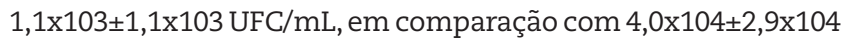
$\mathrm{UFC} / \mathrm{mL}$, nos biofilms controlo $(\mathrm{p}<0.001)$. Conclusões: $\mathrm{O}$ extrato de Cranberry reduziu significativamente a adesão bacteriana dos patógenos periodontais P. gingivalis, A. actinomycetemcomitans e F. nucleatum, nas seis primeiras horas de desenvolvimento do biofilm in vitro, sem afetar a viabilidade bacteriana. Desta forma, este extrato poderá ser benéfico como coadjuvante no tratamento das doenças periodontais. http://doi.org/10.24873/j.rpemd.2019.12.638

\section{\#181 Efeito de preparações ultrassónicas na adesão dentinária utilizando diferentes estratégias}

Elsa Reis Carneiro*, Rui Isidro Falacho, Leandro Martins, Francisco Caramelo, Fernando Guerra

Faculdade de Medicina da Universidade de Coimbra, Faculdade de Odontologia da Universidade Federal do Amazonas

Objetivos: Avaliar e comparar duas técnicas distintas de preparação dentária (pontas ultrassónicas diamantadas vs brocas diamantadas convencionais), quanto à adesão dentinária obtida com duas estratégias adesivas distintas (autocondicionamento vs condicionamento total), por meio de um teste de resistência adesiva por microtração ( $\mu \mathrm{TBS})$. Materiais e métodos: Um total de 16 molares permanentes intactos foram recolhidos, divididos em metades com um disco de diamante e distribuídos em quatro grupos de acordo com o método de preparação e o sistema adesivo utilizado. Uma das metades foi preparada com recurso a ponta ultrassónica diamantada e a outra com uma broca diamantada. Após este procedimento, cada área foi restaurada com resina composta até ser obtido um cilindro de $6 \mathrm{~mm}$ de altura sobre a superfície exposta. Em seguida, os dentes foram seccionados para obtenção de bastonetes uniformes que foram então submetidos ao teste de microtração ( $\mu \mathrm{TBS})$, utilizando uma máquina de testes universal. A análise estatística dos valores obtidos foi realizada pelos testes Shapiro-Wilk e Leven. A influência de ambas as variáveis foi analisada utilizando Two-way ANOVA. Resultados: Não houve diferenças estatisticamente significativas entre os valores médios de força de adesão no que toca ao sistema adesivo $(F(1,24)=1,004, p=0,326)$, nem quanto ao tipo de corte $(F(1,24)=2,505, p=0,127)$, nem no que diz respeito à interação entre os dois fatores $(F(1,24)=0,040, p=0,840)$. Conclusões: Ambas as estratégias adesivas apresentaram valores similares de $\mu$ TBS, portanto podem ser igualmente eficazes independentemente da técnica de preparação. Em relação ao método de preparação, os grupos em que foram utilizados instrumentos ultrassónicos apresentaram os maiores valores de força de adesão, independentemente da estratégia adesiva, embora sem significância estatística. É imprescindível a realização de mais estudos, com aplicação de metodologias standard, para clarificar as relações entre as variáveis testadas. http://doi.org/10.24873/j.rpemd.2019.12.639

\section{\#182 Capacidade mastigatória de indivíduos geriátricos institucionalizados}

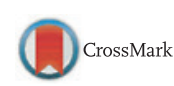

Sarah Goolamhussen*, Joana Maria Figueiredo Ferreira dos Santos, Patrícia Fonseca, Nélio Veiga

Universidade Católica Portuguesa - Instituto de Ciências da Saúde de Viseu

Objetivos: Durante vários anos, as próteses removíveis convencionais foram consideradas o tratamento de eleição para o edentulismo, porém nem sempre são satisfatórias ao nível mastigatório. Este estudo pretende caracterizar a capacidade mastigatória de idosos institucionalizados, portadores ou não de prótese dentária e clarificar a sua vantagem nesta função estomatognática. Materiais e métodos: Trata-se de um estudo observacional transversal com idosos residentes em Viseu, mais concretamente no Lar Viscondessa São Caetano e no Centro Social Paroquial Rio de Loba. Foi obtida uma amostra de 63 indivíduos (44 mulheres e 19 homens), com idades compreendidas entre os 60 e os 99 anos. Na recolha de dados foi aplicado o instrumento de estudo da capacidade mastigatória - Índice de Leake e avaliada a presença de reabilitação protética. A informação recolhida foi introduzida e analisada no software IBM SPSS Statistics ${ }^{\circledR}$ com o limiar de significância estatística de 5\%. Resultados: A maioria dos pacientes com prótese dentária $(61,9 \%)$ consegue mastigar alimentos moles sem dificuldade, como a salada (81\%) e os legumes cozidos (68,3\%). Apesar de conseguirem comer com dificuldade alimentos mais consistentes como a carne $(49,2 \%)$ tendem a evitá-los. Uma grande parte dos idosos sente dificuldade a mastigar alimentos duros e mais de metade dos não reabilitados não conseguem mastigar estes alimentos. Verifica-se uma relação estatisticamente significativa entre a presença de prótese e a capacidade mastigatória de alimentos duros $(p<0,05)$. Apesar da capacidade mastigatória dos idosos portadores de prótese ser superior aos não portadores, os alimentos mais duros tendencialmente são evitados e a alimentação adotada tende a ser idêntica em ambos os grupos. Conclusões: Dado o crescimento exponencial de indivíduos geriátricos na população portuguesa e uma vez que as suas reabilitações protéticas influenciam diretamente a sua capacidade mastigatória, é imprescindível avaliar e corrigir a qualidade das mesmas de forma a incrementar a qualidade de vida destes portadores. http://doi.org/10.24873/j.rpemd.2019.12.641 